\title{
Rule of Law and Political Representation
}

\author{
Donald Bello Hutt ${ }^{1,2} \mathbb{0}$
}

Accepted: 16 October 2021 / Published online: 2 November 2021

(C) The Author(s) 2021

\begin{abstract}
How do the rule of law and political representation relate to each other? I answer this question, hitherto neglected by rule-of-law scholars, taking my cue from Joseph Raz's revision of his conception of the rule of law and by relying on a distinction between preferences and interests, which pervades discussions of political representation. I argue that political representatives' attention to their constituents' preferences, and not just their interests, is a necessary feature of a conception of representation that expresses a robust allegiance to the rule of law. More specifically, that such allegiance is better honoured when representatives are responsive to preferences warranted by public interests. I offer two groups of rule-of-law reasons for that claim. First, because respect for preferences by representatives facilitates the conditions for the law to be obeyed. Second, respect for those preferences through the justification of the representatives' collective decisions allows for accountability and for non-arbitrary creation and application of the law. I finish addressing a threefold objection to my reliance on preferences as objects that representatives should consider when making their decisions.
\end{abstract}

Keywords Rule of law $\cdot$ Representation $\cdot$ Preferences $\cdot$ Public interests · Constitutionalism

\section{Introduction}

"We all know what to do, but we don't know how to get re-elected once we have done it". The quip, attributed to a former Prime Minister of Luxembourg, suggests that the duties of representatives and what their electors prefer are two different things. Consider one of those duties: representatives must respect the rule of law. Nothing controversial about that. However, this also implies that politicians could

Donald Bello Hutt

donald.bello@uva.es

1 Assistant Professor, Moral and Political Philosophy, Philosophy Department, University of Valladolid, Plaza del campus s/n, 47011 Valladolid, Spain

2 Research Collaborator, Institute of Philosophy, KU Leuven, Leuven, Belgium 
honour the rule of law while contradicting their obligation to represent their constituency. Conversely, they may represent the latter while breaching the former.

Of course, how the rule of law and political representation interact, which conception of political representation is more conducive to securing the rule of law, how is the rule of law shaped by different understandings of political representation, or whether political representation is governed by rule-of-law imperatives, depends on how one understands these notions. I here offer an answer to these questions from the perspective, important in theories of political representation and increasingly significant for thinking about the rule-of-law, of the distinction between preferences and interests.

I will expound my claim in more detail, but it is important to lay my cards on the table at this point. It is this: the rule of law is better accounted for and safeguarded if political representatives decide and justify their decisions by considering the preferences of their represented and not just their interests-more specifically, by being responsive to preferences warranted by public interests.

We must understand how and to what extent should preferences be considered, how they interact with interests, and how these notions bear on rule-of-law considerations. Preference-responsiveness, embodied many times through appeals by politicians to the direct "will of the people", is seen as a threat to democracy and the rule of law. Both representative democracy and the rule law are said to be in crisis, ${ }^{1}$ a good amount of conceptual analysis is done on both categories, ${ }^{2}$ there is budding interest in the "rediscovery" of political representation, ${ }^{3}$ and normative and empirical work is needed on both camps. ${ }^{4}$ These pressing concerns are likely to be addressed, if not fully, at least fruitfully, by reflecting on whether and how these ideas interact. However, and surprisingly, we know little about how the rule of law and political representation relate to each other. Therefore, and to the extent that one proceeds carefully, it is a good moment for enriching our understanding of the rule of law from sundry theoretical perspectives without falling prey to charges of conceptual conflation or over-inclusiveness. Political representation is one of such viewpoints.

The argument is inspired by and takes its cue from Joseph Raz's recent revision of his understanding of the rule of law. I will describe that revision, but a brief sketch is helpful here. Raz initially argued that the rule of law is a contingent value of legal systems related to the formal conditions under which the law may be obeyed (1979). Although he stands by the main tenets of his original idea, and for reasons I explain below, he now adds that the doctrine requires government to promote "the interest of the governed" $(2019,8)$.

\footnotetext{
${ }^{1}$ On the idea of crises of democracy, see for example, Ginsburg and Huq (2018a, b); Levitsky and Ziblatt (2018); Runciman (2018); Przeworski (2019). On the crises of the rule of law, see for example, Lavelle (2019); Matczak (2020).

${ }^{2}$ See Sect. 1.

${ }^{3}$ For example, Manin (1997); Urbinati (2000, 760); Ankersmit (2002); Urbinati (2006).

${ }^{4}$ On the concept of the rule of law, see for example, Waldron (2002); Tasioulas (2020). For discussions of the concept and the normative and empirical import of political representation, see for example, Rehfeld (2018, 21); Wolkenstein and Wratil (2020), respectively.
} 
Raz's revision is helpful and matters for three reasons. First, his original depiction of the doctrine is a point of academic reference, so we do well in tracking its evolution. Second, focusing on one target, which is representative of quite vast an array of scholarly writings, keeps my analysis manageable. Third, and more importantly, because Raz's development is a significant expression of a more general trend in the rule-of-law literature of progressively abandoning a divide between formal and substantive conceptions of the doctrine. ${ }^{5}$ I thus use such development not for the purposes of doing an exegesis of Raz or Razian scholarship, but to take his account as representative of a more general transition or transformation in rule-of-law academic literature.

As now defined, Raz's depiction of the rule of law maps onto conceptions of political representation that stress the role of representatives in furthering the interests of their constituents. However, as important as they are, these interests are not the only thing that representatives could and should consider when making decisions; preferences count too. These two categories may or may not converge, and stressing or choosing one rather than the other yields different consequences. For instance, citizens may have preferences that jettison their interests; representatives may act in the interest of their represented contradicting the latter's expressed preferences; representatives may abide by their constituents' preferences and not by what they consider to be their best interests; and so on. Therefore, from the perspective of democratic political representation, ${ }^{6}$ the claim that the rule of law entails custodianship of interests raises the question: what about preferences?

Hence my claim. A representative law-making process that honours the rule of law shall be responsive to the preferences of its constituents. The rule of law and the values it comprises are better accounted for and safeguarded if political representatives decide considering those preferences and not just the interests of their principals - more specifically, if those representatives are responsive to the preferences their constituents may have for policies grounded on public interests, i.e., interests that can be offered as reasons to those persons at the receiving end

\footnotetext{
5 Gardner (2012) and Barber (2018, 116-117), for example, doubt whether the distinction is sound. For Barber, substantivists seem to be answering questions different than one about the conditions under which the rule of law comes about. Tamanaha also calls attention to the flexibility of the boundaries separating formal and substantive theories $(2004$, 156). Regarding Raz's own theory, Drinóczi and BieńKacała have straightforwardly questioned whether it can still be maintained that it is formalist anymore $(2020,9)$. Moreover, one additional way in which Raz's revision may collapse the distinction is by considering Kramer's claim that the substantive or formal nature of the rule of law is dependent on the particular features of the legal system the doctrine informs (2009, ch.2).

6 The notions of political representation and of the rule of law of the kind I am here concerned with are linked to democratic, collective, decision-making practices. I express this caveat aware that the notion of political representation may also cover non-democratic practices (Rehfeld 2006, Saward 2008). The institutions affected by it will be sundry, but they share the trait that their raison d'être is tracing collective decisions to the will of those persons potentially affected by them (Dovi 2018; Tribe 1988, 10); to generate what Böckenforde $(2017,359)$ called a chain of legitimation. The same goes for the rule of law, Raz's account included. The concept may make sense and may be instantiated in non-democratic, nonrepresentative contexts as well; I take no issue with that. But my concern here and the argument I present take democracy as a starting point and as the context that limits that scope of my argument. I thank two referees for calling attention to the need to specify this.
} 
of a collective decision. This conception complies with rule-of-law values better than those taking the consideration of preferences as unnecessary, contingent or impossible, and that limit their normative and institutional exigencies, as it were, to furthering the constituency's interests. The implication is that representative actions severed from the preferences of a constituency will carry heavier burdens of justification in rule-of-law terms; at least with regard to some of the principles comprising the doctrine.

I proceed in four steps. Section 1 overviews the debate on the concept of the rule of law. It starts surveying formalist and substantivist conceptions of the doctrine, and lands on Raz's idea that the rule of law entails custodianship of the interests of the governed.

Section 2 builds the framework upon which the question of the relations between the rule of law and political representation may be analysed. It examines the notions of preferences and interests and their relations. I show that preferences can be warranted by publicly justifiable interests, and that this is relevant for the assessment of how decision-makers do their job qua political representatives.

Section 3 justifies the main contention of this article in two parts. The first part, subsect. 3.1, is positive. It argues that representatives safeguard the rule of law better when they respond to their constituents' preferences for policies underpinned by public interests. The reasons, grounded on rule-of-law principles, are expounded using the vocabulary provided by Raz's recently revised understanding of the doctrine.

Accordingly, I will argue in subsect. 3.1.1 that representative actions responsive to the constituents' preferences comply better than their alternatives with the demand that the rule of law ought to be part of the public culture of the polity it governs. Such actions would honour the moral aspects involved in asking citizens what norms and principles they think should rule their lives in society, and would allow them to internalise the principles of the rule of law, thus contributing to generate the conditions for the law to be obeyed.

Subsection 3.1.2 shows that dynamics of public justification and reason-giving, inherent to a robust rule-of-law requirement of public accountability, are more likely to emerge in representative systems that pay due consideration to what the governed prefer about the laws passed by their representatives, and not just to what the latter consider the former's alleged interests are. This justificatory dynamic is congruent with the how we usually think about what the job of a representative law-maker should be, and with an understanding of the rule of law as avoidance of arbitrariness in the creation and application of the law.

Subsection 3.1.3 briefly discusses how these two rule-of-law strands-concerned with conditions for legal obedience and avoidance of arbitrariness, respectivelycomplement each other within the terms of my argument.

The second part, subsect. 3.2, is defensive, but it clarifies and circumscribes the normative and institutional scope of my argument. I address three forms of the potential objection that asking representatives to track preferences is problematic. The first form of this objection, discussed in subsect. 3.2.1, is constructivist: that it makes little sense to speak of preferences that are prior to the claims made by representatives. In response, I argue that the priority of preferences is neither a claim 
about their ontological status nor about the influence constituents may exert over their representatives, but about who justifies what to whom, and in what terms.

The second form of the objection, examined in subsect. 3.2.2, is that searching for citizens' preferences is untenable in the administration of contemporary government. I reply that this is an institutional matter that can only be presented as a pro tanto objection against my claim. Different institutions working at different levels will deal with this problem differently, and some institutions' allegiance to the rule-of-law may depend on their compliance with principles that are not necessarily related to political representation. Agreed. However, there are domains where the objection fails. Institutions with power to decide on constitutional matters (or) with erga omnes effects have stronger reasons to consider preferences in order to respect the rule of law.

The third form of the objection, explored in subsect. 3.2.3, is a familiar criticism of majoritarian procedures by social-choice theory, namely that no social function results from aggregating individual preferences. The objection leads me to acknowledge that there are constraints on the type of institutional arrangements that are likely to turn my preference-attentive, rule-of-law respectful, notion of political representation into something feasible. The upshot is that deliberative (as opposed to aggregative or purely-majoritarian) democracy is the way to go. Although I am explicit about my preference for this democratic theory, the specifics of its institutionalisation must be discussed elsewhere.

Section 4 concludes. It takes stock and briefly reflects on Raz's revision of his concept of the rule of law. I make clear that my intention is not to provide an exegesis of his account but to use it as representative of a broader theoretical trend or transition in rule-of-law scholarship. Yet, I do conclude that Raz may have inadvertently taken a first step towards thinking systematically about political representation and the rule of law, two concepts traditionally seen as essentially contested or underspecified and whose normative value is widely shared as central for the legitimacy of our legal and political systems. Shakespeareanly, Raz may "have spoken truer than [he] purposed". Whether I am taking his revision "wiselier than [he] meant [we] should", is for my readers to assess. ${ }^{7}$

\section{The Rule of Law: The Doctrine, Principles, and Interests}

The rule of law is "an exceedingly elusive notion" (Tamanaha 2004, 3) ideals "connected more by family resemblance than a unifying conceptual structure" (Solum 2019). Nevertheless, consensus has it that the rule of law is at least related to different formal or functional features pertaining to the conditions under which the

\footnotetext{
7 The original quotation is from The Tempest, scene 1.

8 See also Waldron (2002, 139; Bingham (2010, 5); Kristan (2017, 19). The elusiveness I here refer to is conceptual and normative. Some historical analyses are related to the analytical distinction between formal and substantive versions of the rule of law I here draw on but they are less relevant for my purposes here. See, for example, Bingham (2010, 12-38); Tamanaha (2004); Waldron (2020).
} 
law is created and applied reasonably. This in order to control the exercise of public power and coercion (e.g., Lovett 2016, 106-108), so that people may plan their lives in advance (e.g., Raz 1979, 220; Christiano 1996, 20; Sunstein 2018, 123). Scholars usually present lists of such conditions including generality, promulgation, prospectivity, clarity, coherence, stability, consistency in application, predictability, accessibility, enforceability, inter alia (e.g., Fuller 1969; Waldron 2002, 154; 2011, 316-317; Sunstein 2018, 120-122; Tasioulas 2020, 120-121). This equates the ideal to something akin to Doris Lessing's description of Lobengula's rule in The Grass is Singing: "everyone knew what they could or could not do".

Although some limit the definition of the rule of law to these formal desiderata, ${ }^{9}$ others add substantive criteria. ${ }^{10}$ They include, for example, the safeguard of human rights (Bingham 2010, 66), defence of private property (Cass 2004, 131), or protection of human dignity (Stein 2009, 302).

Some have been wary of rule-of-law substantivism. They argue that substantive criteria require specification and are open for dispute, which hinders our capacity to understand the concept (Waldron 2002, 139). Moreover, our allegiance to the rule of law does not imply that it contains all values we hold dear (Tasioulas 2020, 124).

Raz's original analysis has been an exemplar of this formalist approach. If the rule of law, he affirmed, "is the rule of the good law then to explain its nature is to propound a complete social philosophy" (1979, 210-211). Accordingly, he defined it as a virtue that legal systems may or may not have (1979, 211) — a morally neutral instrument "for achieving a variety of goals" (Tasioulas 2020, 124). ${ }^{11}$ This view implied that the basic intuition from which the rule of law derives is that the law must be capable of guiding the behaviour of its subjects (Raz 1979, 214). For this purpose, Raz considered that laws "should be prospective, open, and clear", "relatively stable" so that people are able to make short- and long-term plans $(1979,215)$, and that their creation "should be guided by open, stable, clear and general rules" $(1979,215)$. Additionally, the independence of the judiciary must be guaranteed, the principles of natural justice observed, and a system of courts with reviewing powers over the implementation of the other principles should be made easily accessible to citizens. Finally, "the discretion of the crime-preventing agencies should not be allowed to pervert the law" (1979, 218).

But Raz now finds this initial approach to the concept problematic in ways, as I mentioned in the introduction, that map onto broader changes in the rule-of-law scholarly literature. On reflection, he seems to suggests, our understanding of the concept requires more elaboration. First, because there is no legal criterion determining an acceptable degree of compliance with the aforementioned principles. Inasmuch as the officials' discretion is an unavoidable feature of legal practice, individuals having legal reasons for action will depend not on rules laid down in

\footnotetext{
9 Dworkin called them "rule book" conceptions $(1985,11)$ and Gardner $(2012,196)$, commenting on Barber (2004), "legalistic". Common examples are Fuller (1969, 153); Raz (1979); Hayek (2001, 75). For other examples see Summers (1993) and Tamanaha (2004, 91-101).

10 In support of this assertion, see Tamanaha (2004, 103-114); Craig 1997, 467); Barber (2018, 116).

11 For a criticism of this standard interpretation of Raz, see Bennett (2011).
} 
advance but on the verdicts issued by those creating and applying the law (2019, 4). This incumbers the citizens' capacities to predict the legal consequences of their actions.

As a result, Raz now analyses a second possibility. The rule of law could mean that government owes fidelity to the law. But faithful application of the law by government may be reasonable in morally legitimate polities. What about immoral legal systems? There may be reasons for officials not to apply some laws. Would this mean that government is not abiding by the doctrine? Not necessarily, thinks Raz. Government may indeed choose to be indifferent to certain laws. But a problem certainly arises when government is indifferent to the application of morally legitimate laws. Discretion in their application cannot entirely depend on the government's claims $(2019,6)$. There must be something else to the concept.

Raz then takes a final stab: the rule of law requires government to promote the interest of the governed. "Understood broadly, e.g., to include their moral interests" $(2019,7)$. Three ideas coalesce around such notion $(2019,7)$. In his wording:

a. The interests of all the governed should be given their proper significance and importance.

b. Custodianship the governed, broadly understood, include anyone directly impacted by government action... Governments are custodians of the public interest of those whose governments they are...

c. Manifest intention ... the test of conformity to the rule of law is acting with manifest intention to serve the interests of the governed, as expressed by the law and its morally proper interpretation and implementation.

In turn, this revised understanding of the doctrine focused on interests "requires conformity to what we know as the main features of public accountability" $(2019,8)$. Six principles adding to his original list follow from such requirement. Again, in his words $(2019,8)$ :

Government is by law-meaning:

- The process of reaching the decision should be fair and unbiased;

- It should also allow proper opportunities to consider relevant arguments and information (various degrees of representation and hearing are involved);

- The decisions should be reasonable, relative to their declared reasons. Unreasonable decisions raise doubts whether they were taken for the declared reasons.

- Presumptive conventions: ... In practice, rule of law requirements are met by officials conducting legal business according to conventions of how to do so ... These conventions raise a double rebuttable presumption: that observing them serves the interests of the governed and that the officials who follow them act in the interest of the governed, as they see it.

- The doctrine of the rule of law and its main implications should be part of the public culture, embedded in education and public discourse, and taken as 
obvious and vital by all. The principles it embodies should be above political controversy, though their detailed implementation will not be $(2019,3,8)$

These added tenets explicitly link the rule of law to representation and to how government considers, safeguards, and promotes the interests of the governed. But what does that mean, not only for Raz, but for the purposes of answering the more general question of how do political representation and the rule of interact?

One plausible way of improving our understanding of the rule of law from this idea of custodianship of interests, is by paying attention to theories of representation, where the notion of interest is ubiquitous (Pitkin 1967, 156). But theories of representation consider interests in relation to how they interact with preferences. We thus need to examine those two categories and how they interrelate, so that we then understand how they qualify the demands that the rule-of-law may impose on officials qua political representatives. To that analysis I now turn.

\section{Political Representation: Interests and Preferences}

Like the rule of law, political representation is an elusive concept. ${ }^{12}$ Yet, Raz's idea of custodianship of interests provides a starting point. As mentioned in my introduction, the term "interest" is pervasive in discussions of political representation. However, it is one that needs to be assessed alongside preferences.

The distinction between preferences and interests matters conceptually, empirically, and normatively. Politicians use the language of interests to gain public support, but it is not obvious that those interests they claim to advance are related to what constituents prefer (Ågren et al. 2006; Jennings and Wlezien 2015, 659; Lauener 2020). These notions thus give representatives different courses of action and bear differently on the degree to which they are responsive to their constituency.

\footnotetext{
12 And like the rule of law, it has been defined, in Gallie's widely used expression, as "essentially contested" (1955-1956). See, for example Waldron (2002); Rehfeld (2018, 218). I elaborate my own understanding of the concept elsewhere (Bello Hutt 2019, 2020). I will not provide details here. Suffices to say that my account falls broadly within a scholarly trend that derives normative accounts from the standpoint of the representatives' functions (Dovi 2018). On the various meanings of representation, see Sintomer (2013); Mulieri (2016). For accounts calling attention to conceptual inaccuracy in the literature, see, Brennan and Hamlin (1999, 109); Brito Viera and Runciman (2008, 4); Rehfeld (2009, 216; 2018, 219). For recent contributions to the clarification of the meaning of representation, see Mansbridge (2003); Rehfeld (2006, 2009) Fossen (2019).
} 
And yet, these notions and their differences are generally used imprecisely. ${ }^{13} \mathrm{~A}$ word describing interests and preferences and how they relate is thus called for.

A person has an interest in something if that something brings about or promotes her well-being. Therefore, interests relate to preferences as follows: if a person has an interest in something, she has a reason to want, to prefer that something, or to prefer policies conducive to obtaining that something. Accordingly, while preferences have a volitional character (you either want something or you don't), interests motivate, explain, or justify preferences - the latter underpin the former. ${ }^{14}$ Consider, for example, parents acting in the interests of their children irrespective of the latter's particular preferences.

We should also add that there are preferences underpinned by interests that are alien to the public sphere and whose pursuance may be legitimate insofar as those interests are not offered as reasons for collective decisions. ${ }^{15}$ Conversely, some preferences can be underpinned by interests, which can be, conceptually, public and independent of the individuals' life-plans, or of their specific situation in the community. ${ }^{16}$ Yet, it is also true that some preferences underpinned by private interests can be legitimately pursued to the extent that they coincide with public interests. ${ }^{17}$ As said, you may prefer something, but confronted with the question "why?", your answer may appeal either to your own interests, to an interest you have that coincides with the interests of others, or to some purely objective notion of interest that prescinds of you obtaining a benefit from getting what you want.

So, ultimately the question is: what makes a preference worthy of public consideration? What makes a preference public? One plausible answer is that the preferences that should be considered in the public sphere are those championed through public interests; intersubjective reasons that rational and reasonable people would accept because they speak to, consider, and make room for, the preferences of other fellow citizens. ${ }^{18}$ That reply, consonant with a deliberative form of decision-making

\footnotetext{
13 There are some exceptions, on which I rely to elaborate my discussion (Pitkin 1967, 156-167; Birch 1971, 72-105; Brennan and Hamlin 1999; Martí 2006, 57-65). Barring these exceptions, inaccuracy is the norm. For example, Runciman and Brito-Vieira use both notions when discussing the representation of identity groups, distinguishing between silenced groups' interests and the doubtful impartiality of the preferences of dominating groups (2008, 113-114. My emphasis). However, they do not elaborate on the distinction. In turn, Anderson affirms that "[i[f voting were not a means to reaching collective decisions responsive to the desires of the electorate, or if it led to results that systematically undermined the interests of the electorate, it would be worthless" (2009, 213. My emphasis). Also, constructivists use these terms to conceptualise representative claims, but they do not draw further conclusions from that usage. For instance, for Saward, representative claims are claims "to represent the interests of someone or something" (Saward 2010, 38. My emphasis). For Fossen, "their values, preferences, etc." (Fossen 2019, 826. My emphasis).

14 Of course, having a reason to prefer something does not necessarily entail that the respective desire must necessarily be satisfied, all things considered. A reason can be overridden by competing reasons.

15 Preferring, for example, a brand of perfume because it meets my interest in smelling good is irrelevant in the public sphere.

16 For example, the preference of a healthy person for a policy implementing universal healthcare.

17 For example, the preference of a sick person for universal healthcare.

18 See, for example, Estlund (1993, 1463-1467); Bohman (1996, 6); Martí (2006, 63). I will not disambiguate here the meaning of "acceptance" inasmuch as all its different uses share the condition of intersubjectivity. As portrayed, for example, by Vallier (2016)
} 
(Bello Hutt 2020), ${ }^{19}$ and which places my argument in the public-reason tradition, raises well-known concerns about who is to determine which interests are shared or shareable, what types of reasons count as acceptable in the public sphere, etc. It may raise questions about the ontological status of objective interests too. ${ }^{20} \mathrm{I}$ grant this. Yet, I will bracket out those concerns and rely on the limited but important insight I draw in this section that there is a point at which it is legitimate for representatives to consider preferences.

That point—-preferences for actions warranted by public interests or by subjective interests coincident with public interests-is definitory of perhaps the most conspicuous object a political representative creates when enacting collective norms: law. It is an essential part of representative law-making procedures that their outcome is abstracted from the specific preferences of concrete individuals (Bello Hutt 2020, 364; Fossen 2019). As Waldron puts it,

it is part of the understanding of the very idea of law that we are trying to move away from a direct focus on the unique identity of each person and consider them instead in light of what they have in common...

We want our laws to consider people universably under certain aspects, and as we embark on lawmaking, we want our representatives to present people's interests, concerns, and ideals, universalizably, under certain aspects (2009, 349).

This view informs contemporary understandings of representative law-making, ${ }^{21}$ and has a prominent place in the history of political thought. Sieyès, for example, described this job aptly when arguing that citizens can only be represented with regard to interests that are common among them. Those are the only interests "which and in whose name they can demand political rights or an active part in the formulation of the social law". And this is, for example, the reason why the interests of the privileged were "not something that can be represented" by a national assembly $\left(2003,157\right.$. Emphasis in the original). ${ }^{22}$ This view also shares the features of a rousseauian understanding of legislation. There is more to be said about what Rousseau meant by "law", 23 but a general definition will do for now: laws are, in his understanding, "always general". That is, they consider their subjects "in a body and their actions in the abstract, never any man as an individual or a particular action" $(1997,67)$.

Hence, there is a logical and normative space where preferences and interests converge. And that convergence maps onto the types of tasks expected from lawmakers qua political representatives. Inasmuch as they can meet through intersubjective justification, then the question whether representatives should champion

\footnotetext{
19 More on this in Sect. 3.2.3.

20 More on this in Sect. 3.2.1.

21 Of course, in different degrees, and for different purposes. See, for example, Urbinati (2000, 760); Habermas (1996, 107); Elster (1998, 111, 114); Waldron (2009, 350); Bello Hutt 2019.

22 I take this discussion on Sieyès from Colón-Ríos $(2020,69)$.

23 See Colón-Ríos detailed discussion of Rousseau's use the term (2020, 33-40).
} 
which interests is tied to the question whether they should consider preferences. I believe they should. What follows is a justification for that assertion in rule-of-law terms.

\section{Political Representation and the Rule of Law}

This section first justifies my claim that rule of law is better accounted for and observed if political representatives factor in the preferences of the represented and not just their interests-more specifically, by being responsive to those preferences warranted by public interests (3.1). It then dispels a threefold objection against my reliance on preferences as objects that political representatives should consider when making decisions (3.2).

\subsection{The Argument}

I here flesh-out my main contention in relation to rule-of-law criteria which are conspicuous in Raz's revision and that scholars share widely. Concretely, the demand that the rule of law ought to be internalised by the governed as part of their public culture and the requirement of accountability. These two principles embody conceptions of the rule of law that emphasise the need for the law to generate the conditions of its compliance, and that highlight that the law should be created and applied in non-arbitrary fashions.

\subsubsection{Public Culture and Conditions for the Law's Obeyance}

Regarding the public-culture condition, a useful place to start is Mill's remarks on representative government. ${ }^{24}$ There we find epistemic and moral insights for paying attention to preferences. On the epistemic side, political representatives better secure the conditions under which the law may be obeyed by their delegates by paying attention to their own considerations about how collective life should be regulated. That attention is likely to contribute to an efficacious application of the law. Consider the following question:

does Parliament, or almost any of the members composing it, even for an instant look at any question with the eyes of a working man? When a subject arises in which the laborers as such have an interest, is it regarded from any point of view but that of the employers of labour? $(1861,33)$

\footnotetext{
${ }^{24}$ Rousseau took on board this epistemological feature too: "If I had to choose by birthplace ... I would have searched for a country where the right of legislation was common to all citizens, for who can know better than they the conditions under which it suits them to live together in a single society" (1987, 26-27).
} 
But there is also a moral issue at stake: that institutions must express consideration and respect for their governed by listening to them. Consider, in that vein, the following remarks:

I do not say that the working men's view of these questions is in general nearer to the truth than the other, but it is sometimes quite as near; and in any case it ought to be respectfully listened to, instead of being, as it is, not merely turned away from, but ignored (1861, 33. My emphasis).

It is "great discouragement to an individual, and a still greater one to a class, to be left out of the constitution; to be reduced to plead from outside the door to the arbiters of their destiny, not taken into consultation within" (Mill 1861, $38)$.

These passages underscore that exclusion from decision-making processes facilitates the weakening of representative government Mill warned against and which is an equivalent requirement for the public internalisation of a rule-of-law culture as described by Raz in his revised account.

The rule of law is thus honoured by the idea that the stability of representative government partially hinges on the conditions that would allow citizens accept the process by which collective norms are applied to them, because they have a chance to participate or to somehow see themselves and their opinions, preferences, desires, etc. reflected or considered in such process. This does not only pertain to the psychology of each and every citizen, but to the circumstances under which rule-of-law abiding societies can expect to have their laws obeyed because they are responsive to their citizens' preferences expressed through their participation. This idea is subscribed by political theorists of all stripes. It is championed by republicans and communitarians, for whom participation is a virtue to be demanded from citizens (e.g., Pocock 1975, 1981; Sandel 1996, 24), but also by republicans, (e.g., Sunstein 1988, 1541; Pettit 2012, 5; Lovett 2014) and liberals (e.g., Rawls 2005, 204) who take participation as instrumental for the preservation of a polity.

The notion that participation and expression of preferences is necessary for representation is anchored in Mill's suggestion that "each is the only safe guardian of his own rights and interests" (1861, 32). However, and as Mill himself observes (1861, 33), you could retort that idea wanes in the face of a well-known fact: it is always possible to find decision-makers who are more rational and better informed than their constituents (Martí 2006, 60). So why should preferences matter at all? Why not just finding out what citizens' interests are, in a Burkean vein (1854), relying on the representatives' and not the constituents' judgement? Since participation is no guarantee of correctness, one could argue that well-functioning paternalistic system of governments could indeed produce good outcomes in the interest of the public.

But rule-of-law related considerations lead us to be cautious about that conclusion. ${ }^{25}$ A legal and political system should be able to offer citizens reasons related not only to the benefits ensuing from the content of the decision adopted, but

\footnotetext{
25 Other types of reasons too. For example, Bhatia has argued that participation and responsiveness to preferences matters even if people are not always the best judges of their own interests (2020).
} 
content-independent reasons that can allow them to trust that future decisions will also be of a kind they may consider normatively acceptable. But no system of government systematically ignoring the preferences of its citizens can guarantee this. What counts as a good or a bad decision is always up for disagreement, and the legitimacy and social acceptance of government hinges to a great degree on why citizens would be willing to put up with decisions whose content they might disagree with.

This latter dimension of democratic representation instantiates the rule-of-law principles of predictability and prospectivity; the possibility for individuals to anticipate future outcomes because they exhibit preference-attentive patterns in the ways collective decisions are made. And these principles are an integral part or inform a conception of the rule of law concerned with the conditions under which the law may be obeyed. Representatives promising courses of action, say, during campaigns, appeal to the preferences of the groups they are targeting not merely for the instrumental reason of getting into public office-although of course this is one motive they do so in practice (Brito Viera and Runciman 2008, 118) - but because then citizens may have access to a set of ideas against which they can assess the future performance of their government. We must be able to predict how officials will behave. Their prerogatives are too grand and affect our lives too directly (Waldron 1989, 84).

\subsubsection{Accountability and Non-Arbitrariness}

These considerations connect with an additional dimension linking political representation and the rule of law: accountability. In turn, just as prospectivity and predictability shape a conception of the rule of law that emphasises that its value lies in the conditions under which legal mandates can be followed by their addressees, accountability through justifiable consideration of preferences expresses and shapes a conception of the rule of law associated with the avoidance of arbitrariness.

I could first state the issue in a negative way. That is, that one possible implication of my view is that attention to preferences seems to entail endorsing something like imperative mandates, for it stresses the need for citizens to see themselves and their preferences reflected, as it were, in decisions adopted by their representatives. But, someone could reply, that conclusion reflects a view-the delegate/trustee distinction-that is rightfully discredited in the literature, ${ }^{26}$ because it ignores that representatives always interpret the preferences and interests of their constituents, ${ }^{27}$ and because this distance between them is not only unavoidable, but normatively desirable. ${ }^{28}$ The circumstances under which governments decide often require that initially promised courses of action be changed or abandoned: representatives are frequently presented with unforeseen difficulties and scarce resources, or see themselves forced

\footnotetext{
${ }^{26}$ However, consider Colón-Ríos discussion on the importance of the imperative mandate for contemporary scholarship and constitutional practice (2020, 77, 267-271).

27 I am here following Pitkin (1967, 155-157). In the same vein, Alonso et al. (2011, 7); Fossen (2019, 834).

28 As it happens, I have advocated for such distance (Bello Hutt 2019).
} 
to compromise with other political forces to gain future support for policies not initially included or ranking lower on their programmes, they may be confronted with better arguments, new information, etc.

However, this, which prima facie conflicts with the notion that preferences matter, can be better accounted for by saying that in order for the principles of the rule of law to obtain, responsiveness to preferences has to be part of the language of representatives when justifying their decisions. If decision-makers are forced to decide contrary to those preferences, they ought to justify why the expectations they raised when asking for public support were not met in the end, not only in terms of why the chosen course of action is in the best interest of the governed, but in terms of why the policies they adopted and the ones their constituents' would have preferred, differ. Such justificatory dynamic can only emerge if representatives are bound to track the preferences of their governed and use them as argumentative tools for justifying their decisions.

Offering justifications to the governed that appeal to their preferences, rather than just appealing to self-referential or solipsistic standards of reasons that speak to interests, is more likely to trigger processes of public accountability. Through them, citizens may internalise that they are part of the public because they are entitled to justifications. Those entitlements are more likely to permeate society with the type of public culture Raz considers as integral to a rule of law-abiding legal system than one that paternalistically furthers only what government considers as a proper course of action. A practice of justification that considers preferences gives citizens reasons to be attentive to the process through which decisions are made by their representatives, on their behalf, but without assuming that government is bound to adopt a quidnunc mentality ${ }^{29}$; a paternalistic attitude towards them. Again, Mill put it aptly:

[t]hus even private morality suffers, while public is actually extinct. Were this the universal and only possible state of things, the utmost aspirations of the lawgiver or the moralist could only stretch to make the bulk of the community a flock of sheep innocently nibbling the grass side by side $(1861,39)$.

A recent example in German politics illustrates my point. Speaking in the German Parliament, Angela Merkel argued that the measures implemented in November 2020 to reduce the number of infections and deaths resulting from COVID19, proved not effective enough. This meant that German citizens would face even stronger limitations of their fundamental rights during Christmas time. She appealed to German citizens in the following preference-attentive and interest-attentive terms:

If we have too much contact over Christmas and afterwards it turns out that that was the last Christmas with our grandparents then we will have really messed up, and we should not mess up... As hard as this is, and I know how much love has gone in to setting up the mulled wine stalls and the waffle stands, this is not compatible with the agreement to only get food to go, and

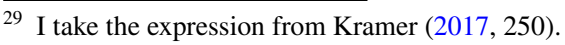


then to actually go home with it. It hurts me, really aches in my heart, but if the price of these niceties is that our fatalities, are now at 590 people a day, then this is not acceptable, and so we have to tighten this.

\subsubsection{Complementarity}

The public-culture condition is more strongly expressive of a conception of the ruleof-law as a set of conditions guaranteeing that the law may be obeyed. Accountability informs a conception of the rule-of-law more closely associated with avoidance of arbitrariness.

Now, these two strands could stand in tension with each other. For example, an effective application of the law could perhaps be better secured by reducing the justificatory demands imposed on officials. Legal obedience is to a large extent sustained on the expectation that subjects will be able to understand the law, to guide their behaviour according to legal requirements, and to apply them without the permanent intervention of legal officials. Every day, contracts are signed, traffic-lights respected, obligations met, etc., and none of these rather simply facts could be taken for granted if citizens were unable to grasp the content of the regulations affecting their lives without asking themselves why they follow the law. That they plan their lives and follow rules without constant official intervention is, prima facie, a sign that the rule-of-law is part of the culture of a society.

But not all rules and standards created and applied by political representatives should or could rely on self-interpretation and self-application. The fact that, say, a constitution tells citizens that the right to life should be respected, says little about the particular cases that may fall under such a vague provision. This is where accountability enters the picture. Accountability, justification for the actions adopted by collective decision-makers increases the possibilities for citizens to know what is it that they are meant to do in the face of disagreements, vagueness, ambiguity, and so on. And, it buttresses the efficacy of the law, and puts into effect the moral imperative that those who suffer a particular decision should be considered in the process leading to its creation and application.

\subsection{A Threefold Objection}

My argument is liable to a threefold objection, which doubts the availability of preferences for representatives to use when adopting decisions. The first version questions the very existence of those preferences (3.2.1), the second our institutional capacity to track them (3.2.2), and the third, their value for the purposes of adopting collective decisions (3.2.3).

My hope is that my answers to these challenges help to clarify the argumentative nature of the duty that my argument imposes on representatives. They should also give us a better sense of the domains within which my normative argument may be more appealing, as well as of the types of institutional arrangements necessary for putting it into practice. 


\subsubsection{Constructivism and the Priority of Preferences}

The first form of the objection comes from constructivist theories of political representation: responsiveness to preferences implies that the represented is in some sense prior to the claims made by the representative. But constructivists deny this.

Constructivists argue that representatives frame the identities of the represented (Dovi 2018; Saward 2010; Dish 2015, 487; Zicman de Barros 2020, 2-4). Accordingly, there are no preferences or interests that are prior to, in Saward's terminology (2010), representative claims. Instead of assuming the existence of preferences that representatives would "bring into" their decision-making process, they ultimately construct them under the form of "claims" that "will resonate with appropriate audiences". ${ }^{30}$ This rebuffs a necessary condition for my argument.

But the objection is misleading. There is no need to conceive of preferences as existing somewhere in the world—as Dworkinian "morons", so to speak (1996, 104; 2011, 42-43). Rather, the issue is about the normative problem of argumentative responsiveness of representatives towards their constituency. I thus side with Fossen: the constructivist objection would hold "if responsiveness required a one-way causal influence, determined by the preferences of their constituents and not the other way around" $(2019,834)$; if what was under discussion was the direction of the influence exerted by one over the other. However, responsiveness (or at least the type of responsiveness that comes with an obligation to justify public decisions) is "about the order of justification"; about who justifies what to whom and in which terms. The represented are prior in the sense that it is their interests that are "fundamentally at stake in representative agency, not those of the representative (Fossen $2019,834)$. And there is no reason not to apply to preferences what Fossen claims for interests. ${ }^{31}$

\subsubsection{Institutional Limitations}

Assume, then, that preferences "are there" for representatives to consider as material from which they can make justified decisions. You may now ask: what is their use, anyway? Governments lack resources for tracking citizens' preferences. They face so many challenges that they must decide on the basis of what the best outcome is in particular situations, not on the bases of what each citizen prefers on each matter of policy. The main instrument citizens have to express their preferences, the ballot, is too limited an informational mechanism. It contains too much information, diversity of demands, preferences, expectations, opinions, etc., all expressed in a binary choice. On this reading, preferences should take the back seat.

There is truth in this. The critique is not new (e.g., Birch 1971, 89-105). Nevertheless, limits on implementation do not necessarily lead to the rejection of preference-based accounts of representation. They rather imply that we have good reasons

\footnotetext{
30 I am here adapting Dovi's phrasing (2014).

31 And to be clear, not because I think Fossen is wrong, but because he does not seem to distinguish the two.
} 
to pursue the ideal as much as our institutional possibilities and our knowledge of social theory allows us to. The objection pushes my argument to distinguish normative and institutional levels where the implementation of a rule-of-law abiding and preference-attentive conception of political representation could be institutionally plausible.

I thus agree with taking these insights on institutional limitations seriously. But not without qualifications. The normative insight I here champion-that deviations from preferences supported by public reasons tracking public interests carry higher burdens of justification in rule-of-law terms - still holds. Of course, when creating and applying norms derived from legal sources placed at the lowest echelons of the legal system, officials have to work with sundry incentives and duties other than paying attention to the citizens' preferences. Officials working, for example, at the level of everyday bureaucratic administration, are more likely to pay more attention to the duties or demands of respect for the preservation of the legal system, for administrative efficiency, among others. They have less room for discretion and, to the extent that they are granted interpretive leeway, their behaviour should be always "infused and structured by a conception of the rule of law... that channels and shapes [it] in ways that make it both efficacious and efficacious as law" (Sunstein and Vermeule 2020 , 43. Emphasis in the original), and not as the manifestation of anyone's preferences. Officials conduct their businesses according to some presumptive conventions and practices ( $\operatorname{Raz} 2019,8)$, some of which may have nothing to do with paying attention to what the governed prefer. Granted.

Yet, and, although it may seem unreasonable to demand from government that each decision track the preferences of all the individuals affected by it, it is equally true that at the constitutional level, or with regard to matters of special importance, this is less problematic. That is, asking the people to consider, say, changes to a constitution, may require more inclusion, more perspectives, and more time to reflect on matters that are central for a political community. This means that what in ordinary law-making is a hindrance, in constitutional matters is an actual advantage, and even a necessity (King 2019, 33). I say more about this in the next subsection, but we can say at this point that a criticism of representative preference-tracking on the bases of institutional limitations is stronger if search for preferences is demanded at every level of the legal system. But I neither endorse this, nor I need to do so. My claim is that there are some levels at which the conventions on the bases of which officials decide could incorporate the preferences of their addresses.

These reflections bear on a related rule-of-law point: that the tools by which decision-makers can insert meaning into legal standards are so varied, that the more abstract, and the more axiologically vague those rules and/or standards may be, the more difficult it becomes to meet the promise of rule by law and not by men. My attention to preferences certainly creates the danger of turning the law into a decisional practice. This is no cynicism, but merely the recognition that constitutive features of the law, especially at the constitutional level-where things usually matter the most but where "conversational contexts" are generally "thin" (Marmor 2014, 149)_, make a part of its practice unavoidably bound to the will of the decisionmaker. And this is certainly the case with an account such as mine, which pays attention to a volitional object of the kind the rule of law is precisely meant to control. 
These difficulties are well-known (e.g., Endicott 1999), but they do not entail that the rule of law is wishful thinking. Sanchez-Cuenca implies this when he says that the "law cannot rule. Ruling is an activity, and laws cannot act" (2003, 62). Rather, what they entail is that the promise of rule of law must take into consideration that the tool by which the rule of men is to be controlled for is itself permeated by the problems it purports to solve ( $\operatorname{Raz} 1979,224)$. This is why I have insisted in this article that attention to preferences has rule-of-law benefits, not that it is a sufficient condition for rule-of-law making. Preferences are necessary, but they are not the whole story.

Our institutional arrangements should guarantee that the law is not a pure act of the will but also a rational abstraction enacted by representative institutions whose most conspicuous product is expected to be general and future-oriented. That process - in order to be attentive to the unavoidably volitional aspects of the law, particularly at the constitutional level-should pay attention to preferences and then abstract away from them for the purposes of transforming them into law. ${ }^{32}$

\subsubsection{The Challenge from Social-Choice Theory}

Public-choice theory presents us with a related problem. It is this ${ }^{33}$ : there is, in general, "no fair and rational way of amalgamating voters' preferences to reach a social decision" (Miller 1992, 52). The difficulty it poses for my argument is clear: representatives may rely on preferences, but no outcome that is representative of the community will emerge from that.

I take the challenge at face value. Yet, I will rely on well-known answers to it for a more positive purpose, namely, that the social-choice theory challenge affects certain understandings of democracy, but not others. At least not as profoundly. Nevertheless, it should be taken seriously, for its conclusion bears on what type of representative institutional arrangement would be suited to embody preference-attentive notions of political representation congruent with the demands of the rule of law. ${ }^{34}$

Consider two groups of prominent democratic theories: aggregative and deliberative. ${ }^{35}$ Aggregative democratic theories focus on the accretion of preferences according to some interpretation of the principle of voting. ${ }^{36}$ Deliberative theories

\footnotetext{
32 My discussion proceeds at a level of abstraction that prevents me from entering specifics about institutional design. Space constraints also recommend against delving into such discussions. It should be noted, nevertheless, that preference-attentiveness is compatible with and, as is happens, may demand the existence of political parties articulating those different preferences (as suggested in my Bello Hutt 2020, 363-364). However, at the same time, it is in principle at odds with parties advancing particularistic agendas oblivious to the general interest as a matter of principle.

33 The best-known formulation of that problem is Arrow's "impossibility theorem" (2012). See also Downs (1997); Weale (2018, 46-66).

34 The specifics of the institutional arrangements necessary to implement this idea deserve separate treatment. I undertake such an analysis in Bello Hutt (2019).

35 Following the analogous divide between the market and the forum (Elster 1997).

36 This description includes, for example, Schumpeter's elites competition account (2003, 269-302), Downs' economic theory of democracy (1997), and generally, accounts endorsing some version of social choice theory applied to democratic decision-making (e.g., Buchanan 1954; Hayek 2001; Riker 1982; Buchanan and Tullock 2004). Although they vary in several aspects, they all seem to value the political
} 
argue that collective decisions ought to result from a process of public discussion among free and equal individuals, including every argument and every potentially affected person (e.g., Cohen 1997, 74; 1998, 203; Bohman 1996, 7, 9).

Aggregative theories fall prey to the social-choice-theory challenge inasmuch as their endorsers tend to assume that preferences and interests of the participants in the decision-making process are pre-political, fixed and identifiable (Martí 2006, 67). ${ }^{37}$ However, deliberative theories of democracy have proven to be able to meet the challenge or at least to attenuate its effects (Miller 1992, 60; Mackie 2003; Martí 2006, 198).Deliberativists generally tackle this problem on two grounds. First, deliberation prior to voting structures the range of preferences that will be submitted as alternatives for the final decision. Second, deliberative publicity limits the range of alternatives that are submitted to the process as inputs. Some preferences are purely self-interested, or "are so repugnant to the moral beliefs of the society within which the decisions are being made that no one is willing to advance them in a public context" (Miller 1992, 58). ${ }^{38}$ Deliberative procedures thus filter out a number of preferences that would not survive public scrutiny and structures the alternatives that did survive so that the chances of incurring the problems described by social-choice theories, wane.

This is a rough sketch of two theories that diverge on how they account for the nature and value of preferences. Taking the social-choice theory challenge seriously implies, in the context of my discussion, that the type of democratic theory that is necessary to instantiate a notion of political representation that is respectful of the rule of law because it is attentive to the preferences of the governed, must be deliberative. Elsewhere I elaborate on what types of procedures are the ones that can embody this idea (Bello Hutt 2021a), and the literature is rich in proposals that insert deliberation into the representative process. These include mechanisms of citizen contestation (Pettit 2012, 215), parliamentary deliberation and justification (Wintgens 2006), and various democratic and deliberative innovations (e.g., Ryan and Smith 2014, 12).

I can only mention here what I develop elsewhere. I have championed the creation of constitutional deliberative mini-publics in charge of articulating preferences and interests on constitutional matters, the upshot of which must be employed by representatives to decide and to use as justification for their policy choices (Bello Hutt 2021a). Representatives may not agree with the results of those discussions, with how participants in the imagined mini-public think, with the likely consequences of the implementations of their interpretations of those preferences and interests, or with any other aspect resulting from the engagement with the results obtained. Their

\footnotetext{
Footnote 36 (continued)

process instrumentally (Elster 1997, 3), and many of them regard democracy and the market as "special cases of a more general category of collective social choice" (Arrow 2012, 5). Similar considerations apply to pluralist theories, of which Dahl is the most conspicuous representative (Martí 2006, 68, Held 2006, 170).

37 Though, as Miller indicates (1992, 60), not as immutable.

38 Also, Elster (1983, 36; 1998, 111).
} 
duty is to explicitly consider them in their deliberations and in the justification for their decisions whether they agree or disagree with them.

Those proposals have their own limitations, of course. My intention was to suggest that, given the seriousness posed by the public-choice-theory challenge, my account of representation must be a deliberative one if one is committed to take consideration for preferences as a relevant benchmark of rule-of-law compliance. Within that normative and institutional framework, my argument holds.

\section{Conclusion}

I have given an answer to how the rule of law and political representation relate to each other. Raz's recent revision of his influential conception of the rule of law provided me with a stepping stone and with vocabulary to reflect on those matters. I took my cue from his idea that the rule of law requires government to act as a custodian of the interests of governed. Using the conceptual apparatus of theories of political representation, I argued that it is indeed the case that preferences, and not just interests, matter for a conception of political representation that abides by the requirements of the doctrine of the rule of law.

I finished dispelling three forms of an objection that could be wielded against my argument. The objection questions the very existence of those preferences, the institutional capacity of government to track them, and the capacity of democratic government to use those preferences as indicative of some version of the "will of the people", respectively.

I finish with some words about my starting point. Nothing of what I said here in terms of the role that preferences play clashes, I think, with Raz's own considerations. ${ }^{39}$ Nor have I argued that Raz's position is inextricably wedded to interests, as I have theorised them here. This has been my concern, not his.

Having said that, one consequence I am not sure Raz would endorse, is that my discussion may count as a reason for him to recoil from some aspects of his revision; back from custodianship of interests to arbitrariness as the final stab at what the concept may entail. The reason should be clear now: inasmuch as interests are conceptually different from preferences and are thus assessed from a perspective that does not per se pay attention to the decisional or volitional aspects that are inherent to the law, we fall prey, under the guise of deciding for everyone's best interests, to

\footnotetext{
39 Discussions on the nature of practical reasoning along the lines explained, for example, by Bustamante (2020), suggest that Raz's broader philosophical project is compatible with my argument. The same could be concluded by looking at Raz's service conception of authority to the extent that I limit my argument to answering how the rule of law operates and relates to political representation in democratic contexts. The reason for this is that Raz is adamant that the rule and democratic legitimacy relate to each other only contingently $(1986,56)$. This circumscribes the scope of our potential agreement. I thank two referees of the journal for raising my attention to this point.

Having said this, one must be careful. The agreement or compatibility I here suggest between our accounts, even within the limits expressed, may be challenged by him or by others familiar with his work on grounds that I cannot fully anticipate here, let alone argue against. This is why I offer this as a suggestion in the first place. I cannot here assume what should be argued for in depth, elsewhere.
} 
turn the law (with more likeliness at the higher hierarchies of the sources "ladder") into something tantamount to the will of the decision-maker. By contrast, considering preferences by representatives before abstracting from them when deciding has the double advantage of grasping the volitional aspects of the law - for the actual preferences of citizens are the ones representatives need to consider as material for their practice - as well as its more rational or abstract aspects related to the effects it will have on all addresses irrespective of their preferences.

Finally, abstract law-making of the kind I have endorsed here eases potential tensions between the rationales that underpin attention to preferences on one hand and accountability on the other. While considering concrete preferences honours the public-culture condition, it may actually count against the rule-of-law principle of accountability, inasmuch as the representatives' justifications ought to appeal to public reasons, as mentioned in the preceding section. This may indeed be the case; those tensions may arise and finding an equilibrium may indeed be necessary. I have granted this. But this is a problem affecting a whole array of principles, values, rights and policies in any legal and political system committed to any of such categories. The type of justificatory discourse that representatives may choose for the purposes of honouring all these standards is a demanding and a risky one for them-citizens may not approve of it and they may lose their sits as a result. But there is no magic formula to finding that balance. ${ }^{40}$ Representative decision-making is more craft than science.

Perhaps Raz would disagree. Be that as it may, my aim has not been to rebuff his revision or his understanding of the rule of law more generally. Rather, I meant to use conspicuous tenets of his revision to move the debate on the rule of law and on political representation in some direction that is both interesting and important for its participants.

Acknowledgements Oxford Jurisprudence Discussion Group; Ana Cannilla; Sebastian Lewis; Udit Bhatia; Joel Colón-Ríos; Dimitrios Kyritsis; Pablo Castillo Ortiz; Joseph Raz; Chiara Valentini, Catarina Santos Botelho; Alon Harel; María Caamaño; Ron Levy; Pierre-Etienne Vandamme; Javier Peña; Magios Seminar in Legal and Political Theory; Asociación costarricense de filosofía del derecho y filosofía práctica; Proyecto legitimidad democrática, Universidad de Cuyo; Johan Olsthoorn's Seminar in Political Theory (University of Amsterdam); and Tania Busch Venthur and participants at the Congreso Nacional de Filosofía, Chile, "Tensiones actuales del Estado Constitucional". This research was partially funded by the University of Valladolid through its GIR (Grupo de investigación reconocido) "Teorías jurídicas y políticas de la modernidad".

Funding Open Access funding provided thanks to the CRUE-CSIC agreement with Springer Nature.

Open Access This article is licensed under a Creative Commons Attribution 4.0 International License, which permits use, sharing, adaptation, distribution and reproduction in any medium or format, as long as you give appropriate credit to the original author(s) and the source, provide a link to the Creative Commons licence, and indicate if changes were made. The images or other third party material in this article are included in the article's Creative Commons licence, unless indicated otherwise in a credit line to the

\footnotetext{
${ }^{40}$ Pace some attempts to formalize justificatory reasoning. A prominent example applied to judicial reasoning, is Alexy's weight formula (2003, 2005). I will not discuss this here because of space constraints and because, in any case, I hesitate to call the judiciary a representative institution in the first place (Bello Hutt 2021b).
} 
material. If material is not included in the article's Creative Commons licence and your intended use is not permitted by statutory regulation or exceeds the permitted use, you will need to obtain permission directly from the copyright holder. To view a copy of this licence, visit http://creativecommons.org/licen ses/by/4.0/.

\section{References}

Ågren H, Dahlberg M, Mörk E (2006) Do politicians' preferences correspond to those of the voters? An investigation of political representation. Public Choice 130:137-162. https://doi.org/10.1007/ s11127-006-9077-1

Alexy R (2003) On balancing and subsumption. A structural comparison. Ratio Juris 16(4):433-449

Alexy R (2005) Balancing, constitutional review, and representation. Int J Const Law 3(4):572-581. https://doi.org/10.1093/icon/moi040

Alonso S, Keane J, Merkel W (2011) Editor's Introduction: Rethinking the future of representative democracy. In The future of representative democracy, Cambridge: Cambridge University Press, pp $1-22$

Anderson E (2009) Democracy: instrumental vs. non-instrumental value. In: Christiano T, Christman J (eds) Contemporary debates in political philosophy. Wiley-Blackwell, Oxford, pp 213-228

Ankersmit FR (2002) Political representation. Stanford University Press, Stanford

Arrow K (2012) Social choice and individual values. Yale University Press, New Haven \& London

Barber NW (2004) Must legalistic conceptions of the rule of law have a social dimension? Ratio Juris 17(4):474-488

Barber NW (2018) The principles of constitutionalism. Oxford University Press, Oxford

Bello Hutt D (2019) Political representation as a regulative ideal: a comment on the democratic objection to constitutional review. Revus 38:39-54

Bello Hutt D (2020) Political representation as interpretation: a contribution to deliberative constitutionalism. Ratio Juris 33(4):351-367

Bello Hutt D (2021a) Deliberative, republican, and egalitarian institutional alternatives for popular constitutionalism. Revista Derecho del Estado 48:183-214

Bello Hutt D (2021b) Making what present again? A critique of argumentative judicial representation, canadian. J Law Jurisprudence 34(2):259-281

Bennett MJ (2011) Hart and Raz on the non-instrumental moral value of the rule of law: a reconsideration. Law Philos 30:603-635

Bhatia U (2020) Rethinking the epistemic case against epistocracy. Crit Rev Int Soc Political Philos (CRISPP) 23(6):706-731

Bingham T (2010) The rule of law. Penguin, London

Birch AH (1971) Representation. MacMillan Press, London

Böckenförde E-W (2017) Constitutional and political writings. In: Künkler \& Tine (eds). Oxford: Oxford University Press

Bohman J (1996) Public deliberation. Pluralism, complexity, and democracy. The MIT Press, Cambridge, Massachusetts, London

Brennan G, Hamlin A (1999) On political representation. Br J Political Sci 29:109-127

Brito Viera M, Runciman D (2008) Representation. Polity Press, Cambridge

Buchanan JM (1954) Social choice, democracy, and free markets. J Political Econ 62(2):114-123

Buchanan JM, Tullock G (2004) The calculus of consent. Logical foundations of constitutional democracy. Liberty Fund, Indianapolis

Burke E (1854) Speech to the Electors of Bristol. In: HG Bohn (eds). The works of the right honourable Edmund Burke, London, pp 446-448

Bustamente T (2020) "The Rule of Law and the Government's Role in Our Lives", Jotwell, https://juris. jotwell.com/the-rule-of-law-and-the-governments-role-in-our-lives/

Cass R (2004) Property rights systems and the rule of law. In: Colombatto E (ed) The Elgar companion to the economics of property right. Edward Elgar Publications, Oxford, pp 131-163

Christiano T (1996) The rule of the many. Fundamental issues in democratic theory. Westview Press, Oxford 
Cohen J (1997) Deliberation and democratic legitimacy. In: Bohman J, Rehg W (eds) Deliberative democracy. The MIT Press, Cambridge, Massachusets \& London, pp 67-92

Cohen J (1998) Democracy and liberty. In: Elster J (ed) Deliberative democracy. Cambridge University Press, Cambridge, pp 185-231

Colón-Ríos J (2020) Constituent power and the law. Oxford University Press, Oxford

Craig P (1997) Formal and substantive conceptions of the rule of law: an analytical framework. Public Law 3:467-487

Dahl R (1967) Pluralist democracy in the United States: conflict and consent. Rand McNally, Chicago

Dahl R (1989) Democracy and its critics. Yale University Press, New Haven \& London

Dish L (2015) The constructivist turn in democratic representation: a normative dead-end? Constellations 22(4):487-499

Dovi S (2018) "Stanford Encyclopedia of Philosophy." Political Representation. Edited by Edward Zalta. Accessed 10 10, 2019. https://plato.stanford.edu/archives/fall2018/entries/political-representation/

Downs A (1997) An economic theory of democracy. Addison Wesley, New York

Drinóczi T, Bień-Kacała A (2020) Illiberal constitutionalism and the European Rule of Law. In: Drinóczi T, Bień-Kacała A (eds) Rule of law, common values, and illiberal constitutionalism: Poland and Hungary within the European Union. Routledge, London, pp 3-42

Dworkin R (1978) Taking rights seriously. Harvard University Press, Cambridge

Dworkin R (1985) A matter of principle. Harvard University Press, Cambridge

Dworkin R (1996) Objectivity and truth: you'd better believe it. Philos Public Aff 25(2):87-139

Dworkin R (2011) Justice for hedgehogs. Harvard University Press, Cambridge

Elster J (1983) Sour grapes. Cambridge University Press, Cambridge

Elster J (1997) The market and the forum: three varieties of political theory. In: Bohman J, Rehg W (eds) Deliberative democracy. The M.I.T. Press, London, pp 3-34

Elster J (1998) Deliberation and constitution making. In: Elster J (ed) Deliberative democracy. Cambridge University Press, Cambridge, pp 97-122

Endicott T (1999) The impossibility of the rule of law. Oxf J Leg Stud 19(1):1-18

Estlund D (1993) Who's afraid of deliberative democracy?-On the strategic/deliberative dichotomy in recent constitutional jurisprudence. Texas Law Rev 71:1437-1478

Fossen T (2019) Constructivism and the logic of political representation. Am Political Sci Rev 113(3):824837. https://doi.org/10.1017/S0003055419000273

Fuller L (1969) The morality of law. Yale University Press, New Haven

Gallie WB (1955-1956) "Essentially Contested Concepts." Proceedings of the Aristotelian Society 56: $167-198$

Gardner J (2012) Law as a leap of faith. Oxford University Press, Oxford

Ginsburg T, Huq A (2018a) How to lose a constitutional democracy. UCLA Law Rev 65:80-169

Ginsburg T, Huq A (2018b) How to save a constitutional democracy. University of Chicago Press, Chicago

Habermas J (1996) Between facts and norms contributions to a discourse theory of law and democracy.

M.I.T. Press, Cambridge (Translated by William Rehg)

Hayek F (2001) The road to serfdom. Routledge, London \& New York

Held D (2006) Models of democracy, 3rd edn. Polity, Cambridge

Jennings W, Wlezien C (2015) Preferences, problems and representation. Political Sci Res Methods 3(3):659-681. https://doi.org/10.1017/psrm.2015.3

King J (2019) The democratic case for a written constitution. Curr Leg Probl 72(1):1-36

Kramer M (2009) Objectivity and the rule of law. Cambridge University Press, Cambridge

Kramer M (2017) Liberalism with excellence. Oxford University Press, Oxford

Kristan A (2017) Desde el Estado hasta la ideología judicial: antimanual. Palestra, Lima

Lauener L (2020) Why do citizens vote against their basic political values? Swiss Political Sci Rev 26(2):153-180

Lavelle P (2019) Europe's rule of law crisis: an assessment of the EU's capacity to address systemic breaches of its foundational values in Member States. Trinity College Law Rev 22:35-50

Levitsky S, Ziblatt D (2018) How democracies die. Harvard University Press, Cambridge

List C, Goodin RE (2001) Epistemic democracy: generalizing the Condorcet jury theorem. J Political Philos 9(3):277-306

Lovett F (2014) "Republicanism.” Standford Encyclopedia of Philosophy. 10 11. http://plato.stanford.edu/ cgi-bin/encyclopedia/archinfo.cgi?entry=republicanism

Lovett F (2016) A republic of law. Cambridge University Press, Cambridge

Mackie G (2003) Democracy defended. Cambridge University Press, Cambridge 
Manin B (1997) The principles of representative government. Cambridge University Press, Cambridge

Mansbridge J (2003) Rethinking representation. Am Political Sci Rev 97(4):515-528

Marmor A (2014) The language of law. Oxford University Press, Oxford

Martí JL (2006) La república deliberativa. Marcial Pons, Madrid

Matczak M (2020) The clash of powers in Poland's rule of law crisis: tools of attack and self-defense. Hague J Rule Law. https://doi.org/10.1007/s40803-020-00144-0

Mill JS (1861) Considerations on representative government. The Echo Library, London

Miller D (1992) Deliberative democracy and social choice. Political Stud 40(1):54-67

Mulieri A (2016) Hasso Hofmann and the polysemy of representation. Redescriptions 19(2):127-145

Pettit P (2012) On the People's terms. A republican theory and model of democracy. Cambridge University Press, Cambridge

Pitkin H (1967) The Concept Of Representation. University of California Press, Berkeley

Pocock JGA (1975) The Machiavellian moment: Florentine political thought and the Atlantic republican tradition. Princeton University Press, Princeton

Pocock JGA (1981) Virtues, rights, and manners: a model for historians of political thought. Political Theory 9(3):353-368

Przeworski A (2019) Crises of democracy. Cambridge University Press, Cambridge

Rawls J (2005) Political liberalism. Columbia University Press, New York

Raz J (1979) The rule of law and its virtue. In: Raz J (ed) The authority of law: essays on law and morality. Clarendon Press, Oxford, pp 210-229

Raz J (1986) The morality of freedom. Clarendon Press

Raz J (2019) The law's own virtue. Oxf J Leg Stud 39(1):1-15. https://doi.org/10.1093/ojls/gqy041

Rehfeld A (2006) Towards a general theory of political representation. J Politics 68:1-21

Rehfeld A (2009) Representation rethought: on trustees, delegates, and gyroscopes in the study of political representation and democracy. Am Political Sci Rev 103(2):214-230

Rehfeld A (2018) On representing. J Political Philos. https://doi.org/10.1111/jopp.12137

Riker WH (1982) Liberalism against populism. A confrontation between the theory of democracy and the theory of social choice. W.H.Freeman, San Francisco

Rousseau J-J (1987) Discourse on the origin and foundations of inequality among men. In: Cress D (ed) Basic political writings. Hackett Publishing, Indianapolis, pp 25-110

Rousseau JJ (1997) The social contract. In: Gourevitch V (ed) The Social Contract and other later political writings, by Jean Jacques Rousseau. Cambridge University Press, Cambridge, pp 39-152

Runciman D (2018) How democracy ends. Basic Books, New York

Ryan M, Smith G (2014) Defining Mini-publics. In: Grönlund K, Bächtiger A, Setälä M (eds) Deliberative mini-publics Involving citizens in the democratic process. ECPR Press, Colchester, pp 9-26

Sánchez-Cuenca I (2003) Power, Rules and Compliance. In: Maravall JM, Przeworski A (eds) Democracy and the rule of law. Cambridge University Press, New York, pp 62-93

Sandel M (1996) Democracy's discontent: America in search of a public philosophy. Harvard University Press, Cambridge

Saward M (2008) Representation and democracy: revisions and possibilities. Sociol Compass 2(3):1000-1013

Saward M (2010) The representative claim. Oxford University Press, Oxford

Schumpeter J (2003) Capitalism, socialism and democracy. Rutledge, London \& New York

Sieyès E (2003) "What is the Third Estate?" In Political Writings, edited by Michael Sonenscher, 92-162. Hackett

Sintomer Y (2013) The meanings of political representation: uses and misuses of a notion. Raisons Politiques 50(2):13-34

Solum L (2019) Legal theory lexicon: the rule of law. 28 07. Accessed 11 09, 2020. https://lsolum.typepad. com/legaltheory/2019/07/legal-theory-lexicon-the-rule-of-law.html

Stein R (2009) Rule of law: what does it mean? Minnesota J Int Law 18:293-303

Summers RS (1993) A formal theory of the rule of law. Ratio Juris 6(2):127-142

Sunstein C (1988) Beyond the republican revival. Yale Law J 97:1539-1590

Sunstein CR (2018) Legal reasoning and political conflict, 2nd edn. Oxford University Press, Oxford

Sunstein C, Vermeule A (2020) Law and leviathan: redeeming the administrative state. Harvard University Press, Cambridge

Tamanaha BZ (2004) On the rule of law: history, politics, theory. Cambridge University Press, Cambridge

Tasioulas J (2020) The rule of law. In: Tasioulas J (ed) The Cambridge companion to the philosophy of law. Cambridge University Press, Cambridge, pp 117-134 
Tribe L (1988) American constitutional law. Second. Mineola. The Foundation Press, New York Urbinati N (2000) Representation as advocacy. Political Theory 28(6):758-786

Urbinati N (2006) Representative democracy: principles and genealogy. University of Chicago Press, Chicago \& London

Vallier K (2016) In defence of intelligible reasons in public justification. Philos Q 66(264):596-616

Waldron J (2002) Is the rule of law and essentially contested concept (in Florida)? Law Philos 21:137-164

Waldron J (2008) The concept and the rule of law. Georgia Law Rev 43(1):1-61

Waldron J (2009) Representative lawmaking. Boston Univ Law Rev 89:335-355

Waldron J (2011) Are sovereigns entitled to the benefit of the international rule of law? Eur J Int Law 22(2):315-343

Waldron J (2020) "The Rule of Law." The Stanford Encyclopedia of Philosophy. In: Zalta EN (Ed.). Accessed August 20, 2020. https://plato.stanford.edu/archives/sum2020/entries/rule-of-law

Waldron J et al (1989) The rule of law in contemporary liberal theory. Ratio Juris 2(1):79-96

Weale A (2018) The will of the people. Polity Press, Cambridge

Wintgens LJ (2006) Legisprudence as a new theory of legislation. Ratio Juris 19(1):1-25

Wolkenstein F, Wratil C (2020) Multidimensional representation. Am J Political Sci. https://doi.org/10.1111/ ajps. 12563

Zicman de Barros T (2020) 'Not all claims are representative claims': constructing 'the people' in post-representative movements. Representation. https://doi.org/10.1080/00344893.2020.1853598

Publisher's Note Springer Nature remains neutral with regard to jurisdictional claims in published maps and institutional affiliations. 